\title{
Вплив трансплантації мононуклеарних стовбурових клітин пуповинної крові на відновлення порушеної скоротливої здатності міокарда
}

\author{
Усенко О. Ю. ${ }^{1}$, Якушев А. В. ${ }^{1}$, Матящук А. С. ${ }^{1}$, Костилєв М. В. ${ }^{1}$, Оніщенко В. Ф. ${ }^{2}$ \\ ${ }^{1}$ ДУ «Національний інститут хірургії та трансплантології імені О. О. Шалімова НАМН» (Київ) \\ ${ }^{2}$ ДУ «Національна медична академія післядипломної освіти імені П. Л. Шупика МОЗ України» (Київ)
}

\begin{abstract}
Існуючі методи лікування серцевої недостатності (CH) не вирішують повністю цю проблему, тому в світі триває пошук альтернативних підходів. Одним з новітніх методів є клітинна терапія. В ході низки досліджень було продемонстровано перспективність застосування мононуклеарних стовбурових клітин пуповинної крові (МСК ПК). Проте маловивченим залишається вплив СК ПК на скоротливу здатність міокарда.
\end{abstract}

Мета роботи - проаналізувати зміни скоротливої здатності міокарда та параметрів внутрішньосерцевої гемодинаміки у пацієнтів із серцевою недостатністю після трансплантації мононуклеарних стовбурових клітин пуповинної крові.

Матеріали та методи дослідження. Проаналізовано результати лікування 20 хворих, яким було виконано трансплантацію МСК ПК у комплексі консервативного лікування рефрактерної СН. Всім хворим проводили ЕхоКГ-обстеження до та після трансплантації.

Результати та обговорення. В післятрансплантаційному періоді зареєстровано статистично значуще підвищення фракції викиду лівого шлуночка, переважно за рахунок зниження кінцево-систолічного індексу, а також покращення значень індексу локальної скоротливості в терміні спостереження до 9 місяців.

Висновки. Використання клітинного препарату «Кріоконсервована пуповинна кров людини» в комплексі консервативного лікування рефрактерної форми СН дозволила частково відновити знижену скоротливу функцію міокарда та підвищити ефективність традиційних схем консервативного лікування СН у терміні спостереження до 9 місяців.

Ключові слова: пуповинна кров, стовбурові клітини, знижена скоротлива здатність міокарда, трансплантація, серцева недостатність, лікування.

Захворювання серцево-судинної системи посідають провідні місця в сучасній структурі смертності та захворюваності населення [3]. Ці захворювання асоційовані з розвитком серцевої недостатності $(\mathrm{CH})$, яка є фінальною стадією їх перебігу [4]. За результатами популяційних досліджень приблизно 1-2\% населення індустріалізованого світу мають $\mathrm{CH}$, поширеність якої зростає з віком і становить не менше $10 \%$ у хворих віком понад 70 років [10, 13]. За даними Європейського товариства кардіологів (ESC, European Society of cardiology), СН у 2/3 випадків зумовлена ішемічною хворобою серця [9]. Для перебігу СН зі зниженою систолічною функцією характерний ряд патологічних та адаптивних змін міокарда, які з часом призводять до подальшого зниження його скоротливості, зменшення толерантності до фізичного навантаження, зниження якості життя хворих, збільшення частоти госпіталізації та смертності [9]. Так, до застосування сучасних методів лікування 5-річна смертність хворих сягала $60-70 \%$ з моменту встановлення діагнозу СН [11]. На даний час із застосуванням сучасних способів лікування смертність і частота госпіталізації внаслідок $\mathrm{CH}$ знизилися, проте залишаються на високому рівні $[5,14]$. Відтак у світі йде постійний пошук нових методів лікування.

Одним 3 перспективних напрямів у цій галузі $\epsilon$ трансплантація мононуклеарних стовбурових клітин (ТМСК). Однак дана методика є маловивченою, і деякі питання залишаються відкритими. Дані літератури свідчать про ефективність різних типів СК у відновленні скоротливої здатності міокарда в експериментальних моделях і в малих клінічних дослідженнях [7, $8,12]$, проте, поряд із перевагами, різні типи СК мають і свої характерні ускладнення, що обмежують їх використання в клінічній практиці. Одним з перспективних типів СК, з огляду на аспекти безпеки, є мононуклеарні стовбурові клітини пуповинної крові (МСК ПК), проте вплив даного типу СК на скоротливу функцію міокарда потребує подальших досліджень, а також залишається недостатньо даних про тривалість клінічних ефектів ТМСК ПК у комплексі консервативного лікування пацієнтів із $\mathrm{CH}$.

Метою даної роботи став аналіз змін скоротливої здатності міокарда та параметрів внутрішньосерцевої гемодинаміки у пацієнтів із серцевою недостатністю після трансплантації мононуклеарних стовбурових 
клітин пуповинної крові. Для досягнення поставленої мети було сформульовано такі завдання: 1) дослідити динаміку змін інтегральних показників скоротливої функції міокарда лівого шлуночка: фракції викиду лівого шлуночка, індексу локальної скоротливості до та після трансплантації стовбурових клітин пуповинної крові; 2) проаналізувати показники діастолічної функції серця за параметрами трансмітрального кровотоку до та після трансплантації стовбурових клітин пуповинної крові; 3) визначити ефективність трансплантації мононуклеарних стовбурових клітин пуповинної крові в комплексі консервативного лікування пацієнтів із порушеною скоротливою здатністю міокарда.

Матеріали та методи дослідження. Дослідження базувалося на аналізі перебігу до- та післятрансплантаційного періоду у 20 пацієнтів із СН стадії ІІА-ІІБ, III-IV функціональним класом за NYHA та зниженою (менше 35\%) фракцією викиду (ФВ) лівого шлуночка (ЛШ). Етапами обстеження пацієнтів були обрані: до ТМСК ПК, кінець 1-го, 3-го, 6-го та 9-го місяців після ТМСК ПК. Аналізували виключно результати обстеження, що виконувалися в ДУ «Національний інститут хірургії та трансплантології імені О. О. Шалімова НАМН»; дані амбулаторного обстеження пацієнтів за місцем проживання не враховувались.

ТМСК ПК проводили шляхом внутрішньовенного введення суспензії клітин препарату «Кріоконсервована пуповинна кров людини», розведеної у 200 мл фізіологічного розчину. Клітинний препарат містив: ядромісних клітин $-(0,890-0,950) \cdot 109$, в тому числі CD34+ клітин - $(0,486-0,520) \cdot 109$.

Ехокардіографічне (ЕхоКГ) обстеження пацієнтів проводили за допомогою ультразвукового сканера Aplio 500 (Toshiba, Японія). Для оцінки стану внутрішньосерцевої гемодинаміки і показників систолічної та діастолічної функцій серцевого м'яза використо- вували загальноприйняті методики [6]. Для виявлення локальних порушень скоротливості ЛШ умовно ділили на сегменти: 6 базальних, 6 середніх та 4 апікальних. При напівкількісній оцінці порушень локальної скоротливості розраховували індекс локальної скоротливості (ІЛС), який являв собою суму бальної оцінки скоротливості кожного сегмента (S), поділену на загальне число досліджених сегментів ЛШ (n): ІЛC $=\Sigma \mathrm{S} / \mathrm{n}$, де гіперкінез становив 0 балів, нормокінез відповідав 1-му балу, помірний гіпокінез - 2-м балам, виражений гіпокінез - 3-м балам, акінез - 4-м балам, аневризматичні зміни - 5-ти балам.

Результати та обговорення. До ТМСК ПК пацієнти мали виражену $\mathrm{CH}$ зі значним зниженням систолічної функції міокарда ЛШ (табл. 1). Так, середня ФВ ЛШ у групі пацієнтів становила 24,8 $\pm 4,1 \%$ (референтні значення

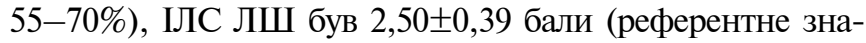

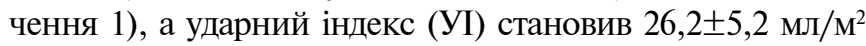
(референтні значення 30-60 мл/м²). Діастолічна функція була порушена за II типом, що підтверджувалося характеристиками діастолічного трансмітрального кровотоку.

Як видно з табл. 1, після ТМСК ПК була зареєстрована позитивна динаміка зміни основних показників внутрішньосерцевої гемодинаміки. Динаміка змін ФВ головним чином була зумовлена зменшенням кінцевого систолічного індексу (KCI), що призвело до збільшення УІ, тоді як коливання кінцево-діастолічного індексу (КДІ) були значно менш виражені. Найбільш суттєві зміни були зареєстровані від початку 3-го місяця спостереження. Слід зазначити, що впродовж всього терміну спостереження ці результати були зареєстровані на фоні практично незмінних показників постнавантаження: артеріальний тиск мав несуттєву тенденцію до підвищення через 3-9 місяців після ТМСК ПК.

Покращення локальної скоротливості міокарда тривало весь термін спостереження (табл. 2). Як ви-

\section{Таблиця 1}

Динаміка показників систолічної та діастолічної функції ЛШ до та після ТМСК ПК

\begin{tabular}{|c|c|c|c|c|c|}
\hline $\begin{array}{l}\text { Показник та одиниці } \\
\text { виміру }\end{array}$ & $\begin{array}{c}\text { До ТМСК } \\
\begin{array}{c}M \pm m \\
(n=20)\end{array}\end{array}$ & $\begin{array}{c}\text { Через 1міс. M士m } \\
(n=18)\end{array}$ & $\begin{array}{c}\text { Чepeз } 3 \text { мic. } \\
M \pm m \\
(n=18)\end{array}$ & $\begin{array}{c}\text { Чepes } 6 \text { мic. } \\
M \pm m \\
(n=14)\end{array}$ & $\begin{array}{c}\text { Через } 9 \text { міс. } \\
M \pm m \\
(n=14)\end{array}$ \\
\hline ФВ ЛШ (\%) & $24,8 \pm 4,1$ & $25,3 \pm 4,5$ & $31,6 \pm 4,8 *$ & $33,3 \pm 4,5^{*}$ & $32,7 \pm 4,9^{*}$ \\
\hline КДІ (мЛ/M²) & $105,9 \pm 14,7$ & $104,3 \pm 17,6$ & $103,2 \pm 19,0$ & $100,4 \pm 11,1$ & $100,3 \pm 11,7$ \\
\hline VI $\left(\mathrm{M} / \mathrm{M}^{2}\right)$ & $26,2 \pm 5,2$ & $25,9 \pm 5,2$ & $32,1 \pm 5,9^{*}$ & $33,5 \pm 6,3^{*}$ & $33,3 \pm 7,5^{*}$ \\
\hline Співвідношення Е/е' & $10,1 \pm 0,9$ & $8,8 \pm 1,5^{*}$ & $9,1 \pm 1,5$ & $9,5 \pm 1,3$ & $9,6 \pm 0,9$ \\
\hline
\end{tabular}

Примітка: е' - ранньодіастолічна швидкість руху мітрального кільця; Е - пікова швидкість раннього діастолічного наповнення ЛШ; А - пікова швидкість пізнього діастолічного наповнення ЛШ; КСІ - кінцевий систолічний індекс; КДІ - кінцевий діастолічний індекс; УІ - ударний індекс; * - статистичні розбіжності з похідним станом значущі $(\mathrm{p}<0,05)$ 


\section{Таблиця 2}

Динаміка середнього ІЛС ЛШ (бали) до та після ТМСК ПК

\begin{tabular}{|c|c|c|c|c|c|}
\hline Сегменти лШ & $\begin{array}{c}\text { До ТМСК } \\
\begin{array}{c}M \pm m \\
(n=20)\end{array}\end{array}$ & $\begin{array}{c}\text { Через 1мic. } \\
\qquad \pm m \\
(n=18)\end{array}$ & $\begin{array}{c}\text { Через } 3 \text { мiс. } \\
M \pm m \\
(n=18)\end{array}$ & $\begin{array}{c}\text { Чepeз } 6 \text { мic. } \\
\qquad \begin{array}{c}M \pm m \\
(n=14)\end{array}\end{array}$ & $\begin{array}{c}\text { Через } 9 \text { міс. } \\
\text { M } \pm m \\
(n=14)\end{array}$ \\
\hline Базальні сегменти & $1,96 \pm 0,43$ & $1,85 \pm 0,43$ & $1,74 \pm 0,39$ & $1,64 \pm 0,32$ & $1,54 \pm 0,35$ \\
\hline Середні сегменти & $2,24 \pm 0,41$ & $2,19 \pm 0,44$ & $2,06 \pm 0,41$ & $2,07 \pm 0,39$ & $1,96 \pm 0,41$ \\
\hline Апікальні сегменти & $3,71 \pm 0,73$ & $3,96 \pm 0,65$ & $3,97 \pm 0,65$ & $3,82 \pm 0,73$ & $3,75 \pm 0,71$ \\
\hline Разом сегменти ЛШ & $2,50 \pm 0,39$ & $2,50 \pm 0,38$ & $2,42 \pm 0,34$ & $2,35 \pm 0,36$ & $2,25 \pm 0,35$ \\
\hline
\end{tabular}

дно з наведеної табл. 2, найгірші показники були зареєстровані в апікальних сегментах ЛШ. Це зумовлено тим, що ділянки з незворотними аневризматичними змінами міокарда (виявлені у 65\% хворих) розташовувались виключно в сегментах верхівки ЛШ серця (відносна кількість сегментів з аневризматичними змінами становила $43,75 \%$ сегментів верхівки ЛШ). Найбільш суттєва позитивна динаміки змін локальної скоротливості була відзначена в базальних та середніх сегментах міокарда ЛШ. Так, у базальних сегментах зниження середнього ІЛС на 3-9-му місяцях після ТМСК ПК становило 11,1-21,6\% від похідного стану, а в середніх сегментах на 3-9 місяцях $-7,6-12,8 \%$ від похідного рівня.

Покращення скоротливої функції міокарда підтверджувалося збільшенням відносної кількості сегментів міокарда ЛШ з нормокінетичним типом скорочення в післятрансплантаційному періоді. Так, якщо до ТМСК ПК в групі пацієнтів нормокінез було зареєстровано в $30,3 \%$ сегментів, то до кінця 1-го місяця після ТМСК ПК - в 37,5\%, до кінця 3-го місяця - в 39,9\%, до кінця 6-го місяця - в $42,9 \%$ та до кінця 9-го місяця спостереження - в 46,4\%. Відносна

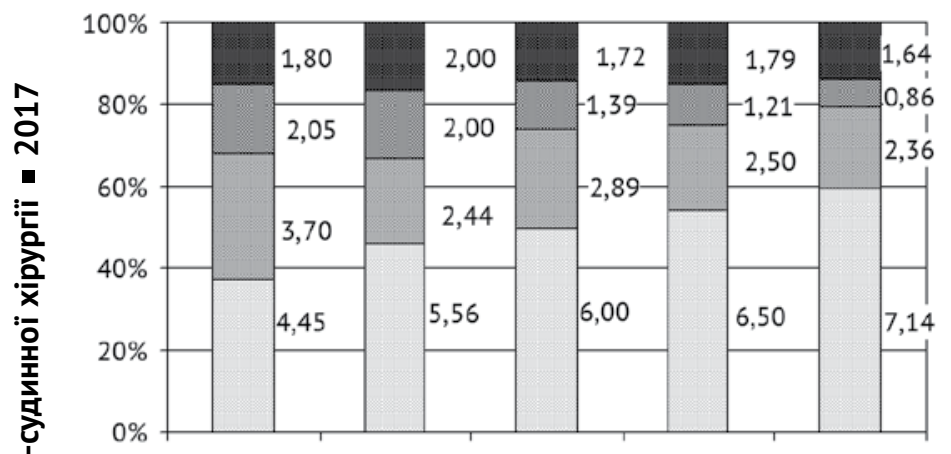

до ТМСK через 1 міс. через 3 міс. через 6 міс. через 9 міс.

$$
\begin{array}{ll}
\square \text { Нормокінез } & \square \text { Помірний гіпокінез } \\
\square \text { Виражений гіпокінез } & \text { Акінез }
\end{array}
$$

Рис. 1. Динаміка змін середньої кількості сегментів з нормокінезом, гіпокінезом та акінезом у базальних та середніх сегментах ЛШ залежно від етапу спостереження кількість сегментів міокарда з порушенням скоротливої функції, відповідно, мала тенденцію до зниження (рис. 1). Таким чином, отримані дані свідчать про значну позитивну динаміку покращення сегментарної скоротливості міокарда ЛШ після ТМСК ПК порівняно з вихідним станом.

В процесі узагальнення ефектів щодо відновлення скоротливої здатності міокарда (табл. 1, 2) встановлено, що в період з 3-го по 9-й місяць спостереження відбувалося динамічне покращення ФВ та ІЛС міокарда ЛШ. Зміни показників ФВ ЛШ та ІЛС ЛШ були взаємопов'язані: коефіцієнт кореляції між ними становив $-0,853$ (рис. 2). ФВ ЛШ на 1, 3, 6, 9 місяці спостереження зросла на $1,9 \%, 27,5 \%, 34,2 \%, 31,9 \%$ відповідно порівняно з вихідним станом; ІЛС знизився на 3,3\%, 6,2\% 10,1\% від рівня похідного стану на 3-му, 6-му та 9-му місяцях після ТМСК ПК.

Відсутність повної синхронності в тенденціях змін ФВ та ІЛС на 6-9 місяцях післятрансплантаційного періоду може бути зумовлена суб'єктивною складовою методики напівкількісної оцінки механіки скорочення ЛШ. Із 9-го місяця спостереження була зареєстрована деяка негативна тенденція зміни скоротливої здатності

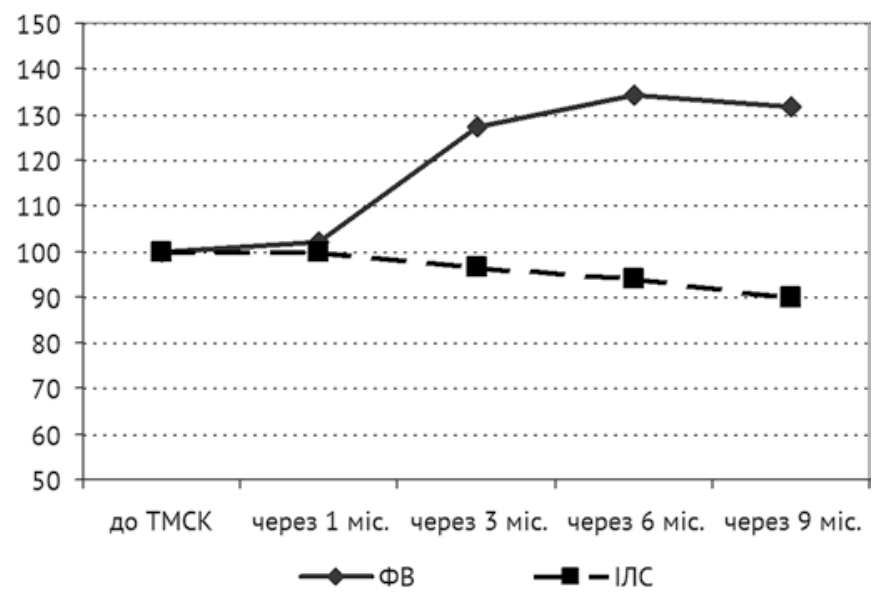

Рис. 2. Динаміка змін (відсоток від похідного стану) ФВ та ІЛС ЛШ після ТМСК ПК в короткострокові та середньострокові терміни 
міокарда ЛШ порівняно з найкращими показниками 6 місяця. Слід зазначити, що несуттєві негативні тенденції на 9-му місяці спостереження порівняно з 6-м місяцем післятрансплантаційного періоду реєструвалися також по середньому функціональному класу NYHA, рівню NT-proBNP крові, оцінці якості життя пацієнтами за анкетами SF-36 та MLHFQ. Хоча з 9-го місяця спостереження і були зареєстровані негативні тенденції зміни ФВ відносно попереднього етапу (6 місяців), порівняно з похідним станом зареєстровані значні статистично значущі позитивні зміни.

При аналізі ЕхоКГ-показників, що характеризують діастолічну функцію ЛШ, жодних статистично вірогідних взаємозв'язків із покращенням систолічної функції ЛШ у пацієнтів після ТМСК ПК протягом всього терміну спостереження встановлено не було. Зміни (в межах до $\pm 20 \%$ від похідного стану) показників е' та Е/e' (табл. 1) були недостатньо інформативні. Майже в усіх хворих зберігався II тип діастолічної дисфункції весь термін спостереження після ТМСК ПК.

Таким чином, за 9-місячний період спостереження зареєстрована суттєва позитивна динаміка зміни систолічної функції ЛШ, що проявлялась як на сегментарному, так і на інтегральному рівні. Можна констатувати, що позитивний клінічний ефект є найбільш значущим у період 3-6 місяців після ТМСК ПК і дещо зменшується до кінця середньострокового (9 місяців після ТМСК ПК) терміну спостереження. Найбільш вірогідним механізмом відновлення зниженої скоротливої здатності міокарда після ТМСК ПК можна вважати прискорення процесів регенерації в міокарді та зменшення морфологічних ознак його ушкодження, що було продемонстровано в ході серії експериментальних досліджень [1, 2].

Висновки. Аналіз динаміки змін за час спостереження продемонстрував, що ТМСК ПК у комплексі консервативного лікування рефрактерної форми СН дозволила частково відновити знижену скоротливу функцію міокарда ЛШ - покращити показники сегментарної скоротливості та ФВ ЛШ протягом всього періоду спостереження. Збільшення ФВ ЛШ зумовлене зменшенням КСI при відносно незмінному КДІ. В ході аналізу було встановлено, що ТМСК ПК у більшості пацієнтів не призводить до суттєвих змін діастолічної функції серця, а іiі динаміка, вірогідно, є вторинною до покращення систолічної функції ЛШ. Таким чином, ТМСК ПК підвищує ефективність традиційних схем консервативного лікування пацієнтів із $\mathrm{CH}$ у короткострокові та середньострокові (до 9 місяців) терміни спостереження.

\section{Література}

1. Вплив трансплантації стовбурових клітин пуповинної крові на експериментальну модель хронічних ураженнях міокарда / Поляченко Ю. В., Габрієлян А. В.,
Доманський Т. М. та ін. // Щорічник наукових праць Асоціації серцево-судинних хірургів України. Вип. 21. Серцево-судинна хірургія. - К., 2013. - С. 376-380.

2. Ефекти стовбурових клітин пуповинної крові при експериментальному ушкодженні міокарда / Поляченко Ю. В., Габрієлян А. В., Доманський Т. М. та ін. // Клінічна хірургія. - 2013. - № 7. - С. 56-60.

3. The global burden of cardiovascular disease / Deaton C., Froelicher E. S., Wu L. H. et al. // Eur J Cardiovasc Nurs. - 2011. - Vol. 10, Suppl 2. - P. 5-13.

4. GBD 2013 Mortality and Causes of Death Collaborators. Global, regional, and national age-sex specific all-cause and cause-specific mortality for 240 causes of death, 19902013: a systematic analysis for the Global Burden of Disease Study // Lancet. - 2015. - Vol. 385 (9963). - P. 117-171.

5. Long-term trends in first hospitalization for heart failure and subsequent survival between 1986 and 2003: a population study of 5.1 million people / Jhund P. S., Macintyre K., Simpson C. R. et al. // Circulation. - 2009. - Vol. 119. P. 515-523.

6. Recommendations for Cardiac Chamber Quantification by Echocardiography in Adults: An Update from the American Society of Echocardiography and the European Association of Cardiovascular Imaging / Lang R. M., Badano L. P., Mor-Avi V. et al. // Journal of the American Society of Echocardiography. - 2015. - Vol. 28 (1). P. $1-39$.

7. Human umbilical cord blood-derived CD133+ cells enhance function and repair of the infarcted myocardium / Leor J., Guetta E., Feinberg M. S. et al. // Stem Cells. 2006. - Vol. 24. - P. 772-780.

8. Cord blood transplantation and stem cell regenerative potential / Liao Y., Geyer M. B., Yang A. J. et al. // Exp Hematol. - 2011. - Vol. 39. - P. 393-412.

9. ESC Guidelines for the diagnosis and treatment of acute and chronic heart failure 2012. The Task Force for the Diagnosis and Treatment of Acute and Chronic Heart Failure 2012 of the European Society of Cardiology.Developed in collaboration with the Heart Failure Association (HFA) of the ESC / McMurray J. J. V., Adamopoulos S., Anker S. et al. // European Heart Journal. - 2012. - Vol. 33. P. $1787-1847$.

10. Mosterd A., Hoes A. W. Clinical epidemiology of heart failure // Heart. - 2007. - Vol. 93. - P. 1137-1146.

11. Roger V. L., Go A. S., Lloyd-Jones D. M. Heart Disease and Stroke Statistics-2011 Update A Report From the American Heart Association // Circulation. - 2011. Vol. 123 (4). - P. 18-209.

12. The role and potential of umbilical cord blood in an era of new therapies: a review / Roura S., Pujal J. M., GбlvezMontyn C. // Stem Cell Res Ther. - 2015. - Vol. 6 (1). P. 123.

13. Thirty-Year Trends in Mortality from Cardiovascular Diseases in Korea / Seung W. L., Kim H. C., Lee H. S. et al. // Korean Circ J. - 2015. - Vol. 45 (3). - P. 202-209.

14. Population impact of heart failure and the most common forms of cancer: a study of 1162309 hospital cases in Sweden (1988 to 2004) / Stewart S., Ekman I., Ekman T. et al. // Circ Cardiovasc Qual Outcomes. - 2010. - Vol. 3. P. $573-580$. 


\title{
Effect of cord blood mononuclear stem cells transplantation on the improvement restoration of decreased myocardial contractility
}

\author{
Usenko A. ${ }^{1}$, Yakushev A. ${ }^{1}$, Matyaschuk A. ${ }^{1}$, Kostilev M. ${ }^{1}$, Onishchenko V. ${ }^{2}$ \\ ${ }^{1}$ State Institution «Shalimov National Institute of Surgery and Transplantology»of the National Academy \\ of Medical Sciences of Ukraine \\ 2 State Institution «Shupyk National Medical Academy of Postgraduate Education» of the Ministry of Health of Ukraine
}

The existing methods of treating heart failure (HF) do not completely solve the problem, so the world is searching for alternative approaches. One of the newest methods is cell therapy. A number of studies have demonstrated the perceptivity of using mononuclear cord blood stem cells (MCB SC). However, the effect of MCB SC on myocardial contractility remains poorly studied.

Aim of study. To analyze the changes in contractility of the myocardium and parameters of intracardiac hemodynamics in patients with heart failure after transplantation of mononuclear stem cells of umbilical cord blood.

Materials and methods. We have analyzed the results of treatment of 20 patients with refractory HF, who underwent MCB SC transplantation in the schedule of conservative treatment.

Discussion. In the post-transplant period, a statistically significant increase in the left ventricular ejection fraction was registered, mainly due to a decrease in the end systolic index, as well as an improvement in the values of the local contractility index at the follow-up period up to 9 months.

Conclusions. The use of the cellular preparation "Cryopreserved human umbilical cord blood" in the schedule of conservative treatment of the refractory HF made it possible to partially restore the reduced contractile function of the myocardium and to increase the effectiveness of traditional schemes of conservative treatment of HF in terms of up to 9 months.

Key words: umbilical cord blood, stem cells, reduced myocardial contractility, transplantation, heart failure, treatment.

\section{Влияние трансплантации мононуклеарных стволовых клеток пуповинной крови на восстановление нарушенной сократительной способности миокарда}

\author{
Усенко А. Ю. ${ }^{1}$, Якушев А. В. ${ }^{1}$, Матящук А. С. ${ }^{1}$, Костылев М. В. ${ }^{1}$, Онищенко В. Ф. ${ }^{2}$ \\ 1 ГУ «Национальный институт хирургии и трансплантологии имени А. А. Шалимова НАМН» (Киев) \\ ${ }^{2}$ ГУ «Национальная медицинская академия последипломного образования имени П. Л. Шупика МОЗ Украины» (Киев)
}

Существующие методы лечения сердечной недостаточности (CH) не решают полностью проблему, поэтому в мире идет поиск альтернативных подходов. Одним из новейших методов является клеточная терапия. В ходе ряда исследований была продемонстрирована перспективность использования мононуклеарных стволовых клеток пуповинной крови (МСК ПК). Однако малоизученным остается влияние МСК ПК на сократительную способность миокарда.

Цель работы - проанализировать изменения сократительной способности миокарда и параметров внутрисердечной гемодинамики у пациентов с сердечной недостаточностью после трансплантации мононуклеарных стволовых клеток пуповинной крови.

Материалы и методы исследования. Проанализированы результаты лечения 20 больных, которым была выполнена трансплантация МСК ПК в комплексе консервативного лечения рефрактерной СН.

Результаты и обсуждение. В послетрансплантационном периоде зарегистрировано статистически значимое повышение фракции выброса левого желудочка, преимущественно за счет снижения конечного систолического индекса, а также улучшение значений индекса локальной сократимости в сроке наблюдения до 9 месяцев.

Выводы. Использование клеточного препарата «Криоконсервированная пуповинная кровь человека» в комплексе консервативного лечения рефрактерной формы СН позволило частично восстановить сниженную сократительную функцию миокарда и повысить эффективность традиционных схем консервативного лечения СН в сроки до 9 месяцев наблюдения.

Ключевые слова: пуповинная кровь, стволовые клетки, сниженная сократительная способность миокарда, трансплантация, сердечная недостаточность, лечение. 